\title{
Awakening the genius within
}

Revolution in the head.

\section{Daniel Gregory}

${ }^{\alpha}$ From ordinary to extraordinary, this machine will make you Shakespeare! Plato! Einstein! Buy it now and awake the genius within! The Inspiron-4000 thinks so you don't have to."

The holographic TV blurted the advert out at a speed too quick to understand at first, but moments later comprehension dawned.

So Martin Williams sat at his desk and thought: a bare featureless landscape lay before him.... a daunting nothingness, the blank page stared back at him. Uninspired. Then he realized what he'd heard.

As a would-be inventor, Martin understood that the key to success was inspiration. None was forthcoming. Time and again he sat down at his desk, only to shrink away from the blank page before him. His life had been reduced to begging and borrowing. He'd drunk and done drugs and turned his modest, beautiful home into a dirty, smelly pigsty. Papers, food, cans of beer accumulated as remnants of his torn-up life. The pieces were everywhere.

He needed ideas.

Martin pressed the buttons on his TV remote and purchased the Inspiron-4000. The Inspiron, which attached directly to the cerebral cortex, was well-known for providing inspiration to many thousands of budding thinkers - inventors, painters, scientists. And the 4000 model was the second in a series, an update of the 3000 model - it should be even better. (The Inspiron- 3000 had apparently inspired its original inventors to greater heights - a self-sustaining system of continual and exponential improvement. Each machine gave the inspiration to improve itself)

A light flashed. Through the magic of teleportation, the Inspiron-4000 materialized in Martin's lounge. He sparkled to life, his senses awake as he tore the packaging apart to reveal the gem inside. Ears and eyes on overdrive, he heard the gentle hum of a far-off space-launch and his eyes recorded a gliding hover-car pass by.

The Inspiron- 4000 gleamed in the sunlight. Its surface was metallic and shone silver in the bright sun. It was perfectly shaped. He fitted it on smoothly. The world faded.

Martin drifted, agile and omnipotent, across the world. Visions appeared like dreams, tangible yet slippery, he gripped at them with his mind. He felt split between worlds - the visions and reality. Snatching at paper he wrote and wrote - great, great works. He grabbed at inspiration, plucking ideas from the ether.

Martin ate and drank nothing. Days passed. He was obsessed and only quietly, from a distance, it seemed, he heard a banging.

“Open up! It's me, Jim."

No one answered. "Open up!"

“Coming...coming, said Martin. "Yeah, capable of! I'll be a new Shakespeare! Plato! Einstein!"

Jim laughed at the ridiculousness of it, but he halted as he saw the look in Martin's eyes. For a moment, he was taken aback. "No - don't use it. Take it off. It's dangerous. Take it off," he repeated. His voice rang with doubt.

“But look - LOOK!" said Martin. "All these works: beautiful, beautiful works! The Inspiron's made something of me - don't you get it? - it's made me a genius. Before I was no one. Now I'm a god! Worship me!"

His dark eyes welled up with tears and a desperate frown spread across his face. He seemed split between two worlds: magnificent papers were strewn across a dingy, messy room. He had done all these things. He was, as he had said, a genius - a god - yet he seemed so animal-like: a sad shadow come full circle from failure to success, and now he was sliding back. He seemed alone. He seemed to teeter on a knifeedge.

"I'm tired of losing," he said.

"Take the damn thing off?" said Jim.

"Nol"

“Take it off? For God's sake, save yourself! Take it off?"

"No."

"Please."

Martin wavered. He strugwait - one minute. I'm coming - one minute." As he opened the door, Martin still had the Inspiron placed tightly on his head. In front of him stood his friend.

"What's that on your head?" he said.

"I'll explain it all later," said Martin. "But look, I’ve been working hard."

"Really?" said Jim. Martin never worked.

$\mathrm{He}$ explained as quickly as he could before rushing to his desk to jot down notes.

The Inspiron was a powerful device. It made you better and better. It wasn't like a drug - it wasn't a question of belief. The Inspiron actually made you better: an addition to the brain, an add-on, updating old technology. It inspired you.

${ }^{\alpha}$ You see, the Inspiron will make me

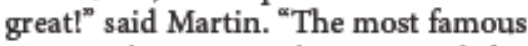
writer and inventor and scientist and philosopher ever! There's nothing I'm not gled, unsure of himself. "Why don't you try it for yourself? You want to, don't you? You'll understand then." A serene, creepy voice. Jim was tempted. He wavered. "I've made another one," said Martin. "I've got two."

A pause. The world stood still.

Jim placed the Inspiron slowly on his head. He saw the visions, the ideas, the possibilities.

“Take it off," said Martin.

"You take it off"

"No. Maybe - wait!"

In the distance there was the gentle hum of a far-offspace-launch. A hover-car glided past. And here had seemed something so hopeful. Teetering on the knife-edge, the humansstruggled against the Inspiron and the talent that it could give them.

Daniel Gregory lives on Anglesey, North

Wales, UK. He can be contacted at dangreg999@aol.com. 